\title{
Pre- and Postpubertal LH and Estradiol Pattern in Gilts Subjected to Intermittent Inescapable Electroshock
}

\author{
By L. J. Pedersen, K. H. Jensen and E. Jørgensen
}

The National Institute of Animal Science, Research Center Foulum, Dept. of Research in Pigs and Horses, Tjele, Denmark.

\begin{abstract}
Pedersen, L.J., K.H. Jensen and E. Jørgensen: Pre- and postpubertal LH and estradiol pattern in gilts subjected to intermittent inescapable electroshock. Acta vet. scand. 1996, 37, 153-161. - The effect of intermittent electroshock on LH and estradiol secretory pattern and on reaching puberty was studied in 24 prepubertal gilts. Twelve gilts 115-168 days of age received unpredictable and inescapable electroshocks $0-5$ times daily between 8 am and $4 \mathrm{pm}$ and 12 gilts served as controls. At an age of 168 \pm 0.7 days all gilts were moved, regrouped and exposed to a boar for $30 \mathrm{~min}$. Observations for signs of oestrus were carried out twice daily. Indwelling jugular catheters were inserted into 8 gilts on each treatment after the initial boar contact. Blood samples were collected to determine LH profiles for $4 \mathrm{~h}$ every $15 \mathrm{~min}$ on day 2 and day 4 after the initial boar contact. The remaining 4 gilts on each treatment were catheterized one day prior to the initial boar contact and blood was collected to determine LH profiles the day before initial boar contact and day 1 and day 2 after initial boar contact for $6 \mathrm{~h}$ every 15 $\mathrm{min}$. In addition, blood samples were collected and analyzed for $\mathrm{LH}$ and estradiol from all gilts daily at $8 \mathrm{am}, 12$ am and $4 \mathrm{pm}$ for the first 3 days following the initial boar contact and thereafter every $4 \mathrm{~h}$ until the end of oestrus (diurnal samples). Samples taken daily at noon the first 5 days following initial boar contact were analyzed for cortisol. The electroshock treatment significantly increased the age at puberty $(\mathrm{p}=0.04)$ and tended to decrease the mean $\mathrm{LH}$ concentration prior to the preovulatory $\mathrm{LH}$ surge $(p=0.08)$ and the maximal concentration of $\mathrm{LH}$ during the preovulatory $\mathrm{LH}$ surge $(\mathrm{p}=0.07)$. The apparent down regulation of the plasma concentration of $\mathrm{LH}$ was not associated with increased activity in the hypothalamus-pituitary-adrenal axis in that the basal concentration of cortisol was not affected by treatment. This indicates that other physiological mechanisms are involved in stress-induced suppression of LH.
\end{abstract}

puberty; stress.

\section{Introduction}

The age at which gilts reach puberty- the time of first behavioral estrus- and the success of inducing puberty by boar exposure and/or regrouping/relocation appear to vary considerably within herds as well as among herds. The causal relationships in this variation are poorly understood. It has been suggested that the vari- ation as well as the problems with delayed puberty seen in intensively housed gilts (Christenson 1981, Rampacek et al. 1981, Clark et al. 1985, Prunier \& Meunier-Salaün 1989) may be attributed to nonspecific physiological reactions to long term stress.

Several management routines and intensive 
housing methods can alter the activity in the hypothalamus-pituitary-adrenal (HPA) axis and are usually suggested to increase the basal level of plasma cortisol (Barnett \& Hutson 1987). In addition, the cortisol response to different physiological or behavioral challenges may be altered (Ladewig et al. 1993). Furthermore, several studies have shown that treatment with synthetic corticosteroids and ACTH may delay puberty (Esbenshade \& Day 1980) and inhibit the pulsatile secretion of LH (Frautschy et al. 1989 ) as well as the preovulatory surge of LH (Barb et al. 1982) and estradiol (Liptrap \& Cummings 1991, Liptrap 1970). Thus, stressful routines may cause delayed puberty as well. Consistent with this suggestion, comparable changes after exposure to social and experimental stressors have been demonstrated in other species, such as cattle, sheep, mice and primates (Moberg 1991, Rivier \& Rivest 1991). However, it actually remains unclear, whether chronic stress inevitably increases glucocorticosteroid secretion. Recent studies on the effect of chronic stress in pigs and other farm animals indicated, that chronic stress may consist of several successive states or stages, which involve an apparent normalization of the basal levels of glucocorticosteroids (Munksgaard 1994, Jensen et al. 1996a). Thus, the consequence of chronic stress on reproduction in pigs may differ from that seen after exogenous administration of ACTH and/or glucocorticoids. No studies on attainment of puberty in gilts using psychological stressors have been carried out in pigs and it remains to be shown that this can cause delayed puberty through a depression of the pulsatile secretion of $\mathrm{LH}$ and/or through a suppression of the preovulatory LH and estradiol surge.

The purpose of the present experiment was therefore to elucidate the effect of exposure to a standardized psychological stressor during the growing period on the LH and estradiol secre- tory pattern around the time of initial boar exposure and first boar induced ovulation in gilts. Electroshock was chosen as this treatment has caused depression of LH and estradiol in several species (Przekop et al. 1984, Rivier et al. 1986, Pollard \& Cairncross 1977). In addition, electroshock treatment is standardizable and minimizes interference between the stressor and normal biological functions while maintaining similar stimulus situations in the control and stress group. Furthermore, the electroshocks were given intermittent and were inescapable which is also the case for stressors in modern swine production.

\section{Materials and methods}

Experimental animals and treatment

The experiment consisted of 24 female pigs from 12 litters (Danish Large White x Danish Landrace). At an age of 8 weeks the 24 female pigs were moved to a slaughter unit. Each of the pigs were housed with 3 littermates, that were not part of this experiment, in pens measuring $1.8 \mathrm{~m} \times 3.4 \mathrm{~m}$. At an age of $168 \pm 0.7$ days all 24 female pigs were introduced to a mature boar for $30 \mathrm{~min}$. This was the initial boar contact. Immediately after the initial boar contact the gilts were housed individually in new but equally sized pens. All gilts were allowed visual and tactile contact through the partitioning bars to a boar at one side and a gilt to the other side. Twice daily at 9 am and 4 pm observations for signs of oestrus were carried out in the aisle outside the pens, at which time the gilts were allowed nose contact through the bars with several boars. Oestrus was defined as the period during which it was possible to induce the standing reflex by back pressure. The reproductive status of the gilts prior to the initial boar contact was checked by means of plasma progesterone samples taken on days 148, 158 and 168. The progesterone samples showed that none of the gilts had ovulated before day 168 . 
Prior to the experiment littermates were randomly distributed within litters between one of 2 treatment groups: control (12 gilts) or electroshocked (12 gilts). All pigs in a pen were subjected to the same treatment. The electroshock treatment began at 115 days of age and continued until approximately $168 \pm 0.7$ days of age (the day immediately before boar contact). It consisted of 0 to 5 daily sessions of inescapable electroshocks with a minimum time between sessions of $30 \mathrm{~min}$. The electroshocks were administered between 8 am and 4 pm. Each session was made up of 5 electroshocks $(2700 \mathrm{~V}$, $0.25 \mathrm{~mA}, 60-65$ pulses per sec) delivered with intervals of $1 \mathrm{sec}$ and lasting for $0.5 \mathrm{sec}$. To increase the unpredictability of the treatment the number and times of sessions varied between days according to a predetermined schedule that was similar for all litters. The electroshock sessions were delivered from a battery-operated stock goad (EL-PA s.r.l., Saronno, Italy) placed around the neck of the pig in a collar. The control pigs were equipped with a similar collar but received no electroshocks. The stock goad was remotely controlled from outside the building thus preventing the pigs from associating the electroshocks with the presence of humans. Collars were fitted on pigs in both groups 16 days prior to initiation of the electroshock treatment. ${ }^{1}$

Indwelling jugular vein catheters were inserted in 8 gilts on each treatment the day after boar contact. The catheters were inserted under general anaesthesia using $1 \mathrm{ml}$ Azeperonum (Sedaperone ${ }^{\circledR}$, Janssenpharma, Birkerød, Denmark) per $10 \mathrm{~kg}$ body weight followed by $0.6 \mathrm{ml}$ metomidati hydrochloridum (Hypnodil ${ }^{\circledR}$, Janssenpharma, Birkerød, Denmark) per $10 \mathrm{~kg}$.

\footnotetext{
${ }^{1}$ The electroshock treatment was carried out with the permission from the Danish committee for care of experimental animals.
}

body weight. LH profiles were determined from blood samples taken from 12 am to 4 pm every $15 \mathrm{~min}$. on days 2 and 4 after initial boar contact. The remaining 4 gilts on each treatment were catheterized without use of anaesthesia one day prior to the initial boar contact and $\mathrm{LH}$ profiles were determined in blood samples taken from 10 am to $4 \mathrm{pm}$ every $15 \mathrm{~min}$. on the day before boar contact and on days 1 and 2 after boar contact. Furthermore, after the initial boar contact, blood samples were taken daily at $8 \mathrm{am}, 12$ am and 4 pm until day 3 in all gilts and hereafter every 4 h (i.e. at 4 am, 8 am, 12 am, 4 $\mathrm{pm}, 8 \mathrm{pm}$ and $12 \mathrm{pm}$ ) until the end of oestrus (diurnal samples). These samples were all analyzed for LH and oestradiol. The samples taken at 12 noon were in addition analyzed for cortisol. All gilts were slaughtered 21 days after the initial boar contact and the ovaries were macroscopically examined within the day of slaughter for the number of corpora lutea.

\section{Hormonal analyses}

The concentration of luteinizing hormone ( $\mathrm{LH})$ was determined in all samples using a validated Radio-immuno-assay technique for pigs (Stupnicki \& Madej 1976, Kunavongkrit et al. 1983). The concentration of estradiol-17ß $\left(\mathrm{E}_{2}\right)$ was determined in all diurnal samples using a commercial enzyme immunoassay (Amerlite ${ }^{\circledR}$, Amerlite estradiol-17ß assay, Amersham, UK). The concentration of cortisol and progesterone (P4) was determined in the diurnal samples collected at 12 am using a commercial enzyme immunoassay (Amerlite ${ }^{\circledR}$, Amerlite cortisol/progesterone assay, Amersham, UK).

The sensitivity of the assay systems to $\mathrm{LH}, \mathrm{E}_{2}$, cortisol and $\mathrm{P}_{4}$ were $0.22 \mathrm{ng} / \mathrm{ml} ., 4.9 \mathrm{pmol} / 1,3.0$ $\mathrm{nmol} / \mathrm{l}$, and $0.8 \mathrm{nmol} / \mathrm{l}$, respectively. The inter assay variations were for $\mathrm{LH} 11 \%$ (mean $=0.7$ $\mathrm{ng} / \mathrm{ml})$ and $10 \%$ (mean=4.1 ng/ml), for E2 29\% $($ mean $=20 \mathrm{pmol} / \mathrm{l})$ and $15 \%($ mean=64 pmol/1), for cortisol $13 \%($ mean $=21 \mathrm{nmol} / \mathrm{l})$ and $6 \%$ 


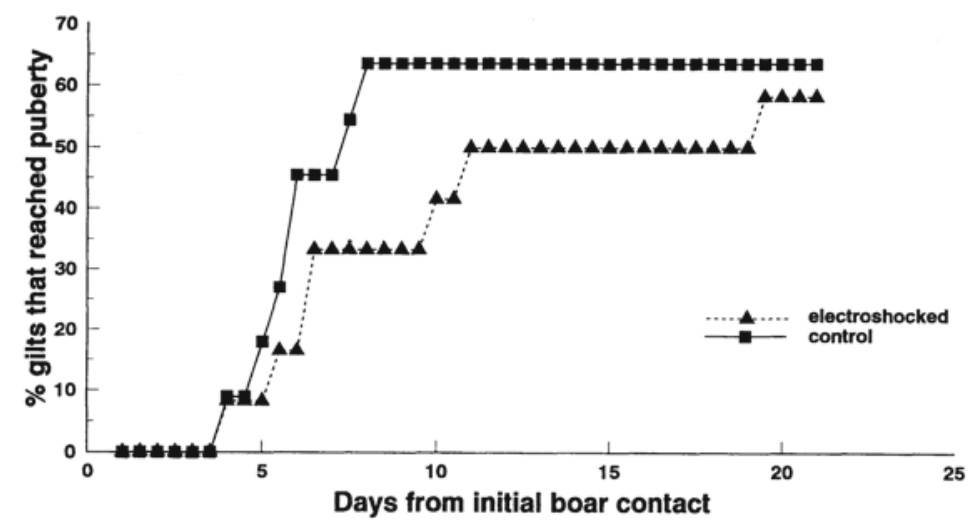

Figure 1. The number of days from initial boar contact to the first oestrus in 11 control and 12 electroshocked gilts.

(mean $=76 \mathrm{nmol} / \mathrm{l})$, for $\mathrm{P}_{4} 13 \%$ (mean=3 nmol/l) and $9 \%($ mean $=22,8 \mathrm{nmol} / \mathrm{l})$. The intra assay variation was for $\mathrm{LH}$ below $10 \%$ in the working range from $0.5 \mathrm{ng} / \mathrm{ml}$ to $10 \mathrm{ng} / \mathrm{ml}$, for $\mathrm{E}_{2}$ below $10 \%$ in the working range from $20 \mathrm{nmol} / 1$ to $149 \mathrm{nmol} / \mathrm{l}$, for cortisol below $15 \%$ in the working range from $21 \mathrm{nmol} / 1$ to $276 \mathrm{nmol} / 1$ and for $\mathrm{P} 4$ below $10 \%$ in the working range from 3 to $160 \mathrm{nmol} / \mathrm{l}$.

LH profile variables were calculated using the Pulsar program developed by Merriam \& Wachter (1982). Predetermined cutoff criteria were set at $\mathrm{G}(1)=3.8, \mathrm{G}(2)=2.6, \mathrm{G}(3)=1.9$, $\mathrm{G}(4)=1.5$ and $\mathrm{G}(5)=1.2$ and the depth criterion for splitting pulses was set at 2.70. Profiles determined after the initial rise of the preovulatory LH surge were excluded (3 profiles from 3 different gilts).

The preovulatory LH and estradiol surge and the interaction between the LH surge and the behavioural signs of oestrus for those gilts that reached puberty ( 7 control gilts and 7 electroshocked) were described by the following variables: 1) the accumulated concentration of estradiol in samples 2 standard deviations above the basal concentration of estradiol (pmol/l) determined from the first day of initial boar con- tact to the initiation of the LH surge, 2) the duration from initiation of the $\mathrm{LH}$ surge to the first standing reflex (hours), 3) the accumulated concentration of LH in samples 2 standard deviations above the basal concentration of $\mathrm{LH}$ (ng/ml), 4) the maximal concentration of $\mathrm{LH}$ (ng/ml), 5) the duration from the first LH sample to the last $\mathrm{LH}$ sample 2 standard deviations above the basal concentration of LH (hours) and 6) the duration from the maximal concentration of LH to the first standing reflex of the gilt (hours). The basal concentration of LH was derived from the mean concentration of the $\mathrm{LH}$ profile determined day 2 . The basal concentration of estradiol was calculated from samples collected later than 1 day after the first standing reflex of the gilt.

The mean plasma concentration of cortisol of day 1 to day 5 after the initial boar contact was used as a measure of the basal concentration of plasma cortisol.

\section{Statistical analyses}

The number of days to reach puberty were analyzed statistically using the Wilcoxons-MannWhitney nonparametric test (Siegel \& Castallan 1988). Gilts that did not reach puberty 
Table 1. LH profiles in control and electroshocked gilts before initial boar contact (LSM \pm S.E.).

\begin{tabular}{lccc}
\hline & $\begin{array}{c}\text { Control } \\
(\mathrm{n}=4)\end{array}$ & $\begin{array}{c}\text { Electroshocked } \\
(\mathrm{n}=4)\end{array}$ & $\mathrm{p}$-value \\
\hline Mean conc. (ng/ml) & $1.10 \pm 0.07$ & $1.00 \pm 0.07$ & 0.42 \\
Smoothed baseline conc. $(\mathrm{ng} / \mathrm{ml})$ & $0.90 \pm 0.05$ & $0.88 \pm 0.05$ & 0.75 \\
Pulses/hour & $0.44 \pm 0.10$ & $0.46 \pm 0.10$ & 0.89 \\
Amplitude of pulses (ng/ml) & $0.82 \pm 0.24$ & $0.84 \pm 0.24$ & 0.95 \\
Duration of pulses (min.) & $58.3 \pm 24.0$ & $64.0 \pm 24.0$ & 0.88 \\
\hline
\end{tabular}

within 21 days post initial boar exposure were included as having 21 days to puberty. All other statistical analyses (LH-profiles, variables of the preovulatory LH and estradiol pattern, the number of corpora lutea, the duration of oestrus and the ln-transformed basal concentration of cortisol) were carried out using a generalized linear model (SAS Institute INC ${ }^{\circledR} 1986$ ), which finally included treatment and litter as fixed effects tested using the variance between animals as the error term.

Statistical analyses of profiles determined before $(2 \times 4$ gilts $)$ and after $(2 \times 12$ gilts $)$ the initial boar contact were made separately. F-tests were performed using Satterthwaite's approximation with the RANDOM statement in the GLM procedure (SAS Institute INC ${ }^{\circledR} 1986$ ). To increase the degrees of freedom for the residual estimate, litters were excluded from the models when its influence was low $(p>0.25)$. Due to problems with different parts of data collection some data were missing. Therefore, the number of experimental units and the degrees of free- dom varied. All analyses were performed as two-sided tests.

\section{Results}

At the time of the initial boar contact the mean body weight of electroshocked and control gilts was 103 and $100 \mathrm{~kg}$. $(\mathrm{s} . \mathrm{e}=1.5)$, respectively. The number of days to the first oestrus was significantly longer $(Z=-1.7 ; p=0.04)$ in the electroshocked group than in the control group (Fig 1).

Treatment did not affect any variables of the $\mathrm{LH}$ profile before initial boar contact (Table 1). After initial boar contact the electroshock treatment tended to decrease the smoothed baseline concentration of LH $\left(\mathrm{F}_{1,19.1}=3.0 ; \mathrm{p}=0.10\right)$ and the mean concentration of $\mathrm{LH}\left(\mathrm{F}_{1,19.1}=3.3\right.$; $\mathrm{p}=0.08$ ) (Table 2).

Treatment tended to affect the maximal concentration of LH during the preovulatory LH-surge $\left(\mathrm{F}_{1,2}=12.1 ; \mathrm{p}=0.07\right)$, in that the electroshocked gilts showed a $20 \% \pm 6 \%$ reduction in the maximal concentration of LH compared to the con-

Table 2. LH profiles in control and electroshocked gilts after initial boar contact ( $\mathrm{LSM} \pm \mathrm{S}$.E.).

\begin{tabular}{lccc}
\hline & $\begin{array}{c}\text { Control } \\
(\mathrm{n}=11)\end{array}$ & $\begin{array}{c}\text { Electroshocked } \\
(\mathrm{n}=12)\end{array}$ & p-value \\
\hline Mean conc. $(\mathrm{ng} / \mathrm{ml})$ & $0.95 \pm 0.13$ & $0.65 \pm 0.13$ & 0.08 \\
Smoothed baseline conc. $(\mathrm{ng} / \mathrm{ml})$ & $1.00 \pm 0.12$ & $0.71 \pm 0.12$ & 0.10 \\
Pulses/hour & $0.48 \pm 0.07$ & $0.36 \pm 0.07$ & 0.25 \\
Amplitude of pulses $(\mathrm{ng} / \mathrm{ml})$ & $0.43 \pm 0.05$ & $0.34 \pm 0.05$ & 0.45 \\
Duration of pulses (min.) & $30.0 \pm 4.4$ & $28.0 \pm 4.3$ & 0.89 \\
\hline
\end{tabular}


Table 3. The preovulatory LH and estradiol surge and the interaction between the LH surge and the behavioural signs of oestrus after initial boar contact in control and electroshocked gilts (LSM \pm S.E.).

\begin{tabular}{lcrr}
\hline & $\begin{array}{c}\text { Control } \\
(\mathrm{n}=7)\end{array}$ & $\begin{array}{c}\text { Electroshocked } \\
(\mathrm{n}=7)\end{array}$ & p-value \\
\hline $\begin{array}{l}\text { Accumulated estradiol determined before } \\
\text { initiation of LH surge (pmol/l) }\end{array}$ & $1142 \pm 269$ & $966 \pm 269$ & 0.65 \\
Hours from initiation of LH surge to & & & \\
oestrus (standing reflex) & $24.0 \pm \quad 3.7$ & $24.0 \pm 3.7$ & 0.99 \\
Total LH above basal level (ng/ml) & $79 \pm 11.4$ & $68 \pm 11.4$ & 0.20 \\
Max. conc. of LH (ng/ml) & $7.0 \pm \quad 0.2$ & $5.6 \pm 0.2$ & 0.07 \\
Duration of LH surge (hours) & $31.0 \pm 3.1$ & $31.0 \pm 3.1$ & 0.99 \\
Hours from max LH to oestrus & $10.0 \pm \quad 3.5$ & $11.8 \pm 3.5$ & 0.83 \\
\hline
\end{tabular}

trol gilts. No significant differences were present between treatments in any measures of the preovulatory $\mathrm{LH}$ and estradiol pattern (Table 3). Neither the duration of oestrus ( $45 \mathrm{~h}$ in control gilts versus $37 \mathrm{~h}$ in electroshocked gilts; s.e. $=2.4)$ nor the number of corpora lutea (12.8 in control gilts versus 13.8 electroshocked gilts; s.e. $=0.7$ ) differed significantly between control and electroshocked gilts.

Treatment did not affect the mean basal plasma concentration of cortisol over the 5 days following boar contact (Table 4).

\section{Discussion}

The results of the present study showed that chronic intermittent electroshock treatment significantly delayed puberty and tended to suppress the basal plasma concentration of $\mathrm{LH}$ and the preovulatory LH surge.

The electroshock treatment used in the present study to mimic psychological stressors in pig production was fulfulling several aspects known to be stressful to pigs. It was aversive, unpredictable and inescapable. Detailed studies were made during the electroshock treatment period on the activity and responsiveness of the HPA-axis and on behavioral responses to the electroshocks in a parallel study using the same pigs as used in the present study (Jensen et al. 1995 b,c). These studies showed that the basal concentration of plasma cortisol was normalized after 4 weeks of electroshock treatment, and still was at the end of the electroshock treatment as indicated by results of the present study. However, the pigs still reacted with the initial behavioural response to the electroshocks, the behaviour of the pigs in the pen had become more passive and the responsiveness of the behaviour and the HPA-axis to acute stress were altered (Jensen et al. 1995, 1996b). These results therefore indicated that at the end of the electroshock treatment (immediately before initial boar contact) the pigs were stressed, even though the basal concentration of cortisol was not elevated. This is in accordance with recent reports which questions the use of high basal

Table 4. The mean concentration of plasma cortisol of 5 days after initial boar contact in control and electroshocked gilts $(\mathrm{LSM} \pm \mathrm{S} . \mathrm{E}$.)

\begin{tabular}{lccc}
\hline & $\begin{array}{c}\text { Control } \\
(\mathrm{n}=11)\end{array}$ & $\begin{array}{c}\text { Electroshocked } \\
(\mathrm{n}=12)\end{array}$ & $\mathrm{p}$-value \\
\hline Mean plasma cortisol $(\mathrm{nmol} / \mathrm{l})$ & $86 \pm 9.7$ & $89 \pm 9.7$ & 0.78 \\
\hline
\end{tabular}


concentrations of plasma cortisol as indicator of chronic intermittent stress (Paterson \& Pearce 1992, Ladewig et al. 1993, Munksgaard 1994).

The delayed puberty and the suppression of baseline concentration of plasma $\mathrm{LH}$ and the preovulatory LH surge were not as large as found during chronic treatment with synthetic corticosteroids in earlier studies in pigs (Estienne et al.1991, Frautschy et al. 1989, Barb et al. 1982, Fonda et al. 1984, Esbenshade \& Day 1980). Individual differences in both the magnitude and quality of the stress response may in part contribute to the lack of large statistically significant differences between treatment groups in the present study. However, the basal concentrations of plasma cortisol were not elevated after 6 weeks of chronic intermittent electroshock treatment, which may suggest that other physiological systems than the HPA-axis may contribute to or be responsible for the stress-induced suppression of gonadotrophin release in the pig. For example, beta-endorphines acting centrally with CRF and independently of the adrenal gland may play an important role in stress induced inhibition of LH as indicated by results of Rivier et al. (1986) and Xiao et al. (1989). Furthermore, during stress, a number of other monoaminergic and peptidergic reactions at the brain level are activated (Ladewig et al. 1993). Studies on the castrated littermates to gilts used in the present study indicated increased turnover rate of serotonin in the CNS of the electroshocked pigs (Jensen et al. 1995). Since several neurotransmitters, such as catecholamines and serotonin, are involved in the regulation of gonadotrophin secretion in undisturbed animals (Weiner et al. 1988, Kraeling \& Barb 1990), they may also play an important role in LH-suppression during stress. Such evidences, combined with the results of the present study, may therefore question the use of treatment with synthetic glucocorticoids or
ACTH as a model for studying stress-related suppression of the HPG-axis in the pig.

In other species, however, more dramatic effects of chronic treatment with electroshock have been found on activity in both the HPAand the hypothalamus-pituitary-gonadal-axis (HPG-axis) (Przekop et al. 1984, Rivier et al. 1986, Pollard \& Cairncross 1977). Such divergent results among different species may reflect species differences in the sensitivity of the HPG-axis to stress as well as differences caused by the experimental procedure such as the intensity and duration of the electroshock sessions.

In conclusion, treatment of prepubertal gilts from an age of 115-168 days with daily intermittent inescapable electroshocks significantly $(p=0.04)$ delayed puberty and tended to decrease the smoothed baseline concentration of $\mathrm{LH}$, the mean concentration of LH and the maximal concentration of the preovulatory $\mathrm{LH}$ surge. The down regulation of plasma concentration of gonadotrophin seemed not to be caused by increased activity in the HPA-axis since the basal concentration of cortisol was not affected by chronic electroshock treatment. This indicates that other physiological mechanisms may have been involved.

\section{Acknowledgement}

This study was supported by The Danish Agricultural and Veterinary Research Council, Copenhagen, Denmark. The authors wish to thank the Department of Clinical Chemistry, Swedish University of Agricultural Science, where the analyses of LH and estradiol-17ß were carried out.

\section{References}

Barb CR, Kraeling RR, Rampacek GB, Fonda ES, Kiser TE: Inhibition of ovulation and LH secretion in the gilt after treatment with ACTH or hydrocortisone. J. Reprod. Fert., 1982, 64, 85-92.

Barnett JL, Hutson GD: Objective assessment of welfare in the pig: Contributions from physiology and behaviour. In: Barnett J.L. et al.(eds): Manip- 
ulating pig production. Australasian pig science association, Werribee, Victoria, Australia. 1987, pp 1-22.

Christenson $R K$ : Influence of confinement and season of the year on puberty and estrous activity of gilts. J. Anim. Sci., 1981, 52, 821-830.

Clark JR, Bell RW, Tribble RW, Lennon AM: Effects of composition and density of the group on the performance, behaviour and age at puberty in swine. Appl. Anim. Behav. Sci., 1985, 14, 127135.

Esbenshade KL, Day BN: The effects of triamcinolone acetonide on plasma glucocorticoid levels and occurrence of estrus in gilts. J. Anim. Sci., 1980, 51, 153-157.

Estienne MJ, Barb CR, Kesner JS: Luteinizing hormone secretion in hypophysial stalktransected gilts given hydrocortisone acetate and pulsatile gonadotrphin-releasing hormone. Dom. Anim. Endocrinol., 1991, 8, 407-414.

Fonda ES, Rampacek GB, Kraeling RR: The effect of adrenocorticotropin or hydrocortisone on serum, luteinizing hormone concentrations after adrenalectomy and/or ovariectomy in the prepuberal gilt. Endocrinology, 1984, 114, 268-273.

Frautschy SA, Gaon D, Liptrap RM: Effect of dexamethasone on gonadotrophin secretion in the gonadectomized sow and boar. Can. J. vet. Res., 1989, 53, 490-492.

Jensen $K H$, Pedersen $L J$, Giersing Hagelsø AM, Heller KE, Jørgensen E, Ladewig J: Intermittent stress in pigs: Behavioural and pituitary-adrenocortical reactivity. Acta Agric. Scand., 1995, 45, 276-285.

Jensen $K H$, Hansen $S$, Pedersen $L J$ : The effect of long-term stress on the hypothalamicpituitaryadrenocortical axis and the role of the stressor. Acta Agric. Scand., 1996a, In press.

Jensen $K H$, Pedersen LJ, Nielsen EK, Heller KE, Ladewig J, Jørgensen $E$ : Intermittent stress in pigs: Effects on behaviour, pituitary-adrenocortical axis, growth and gastric ulceration. Physiol. Behav., 1996b, In press.

Kraeling RR, Barb C.R: Hypothalamic control of gonadotrophin and prolactin secretion in pigs. J. Reprod. Fert., 1990, 40 (Suppl.), 3-17.

Kunavongkrit A, Kindahl H, Madej A: Clinical and endocrinological studies in primiparous zeroweaned sows. 2. Hormone patterns of normal cycling sows after zero-weaning. Zbl. Vet. Med. A., 1983, 30, 616-624.

Ladewig J, de Passillé AM, Rushen J, Schouten W,
Terlouw C, Von Borell E: Stress and the physiological correlates of stereotypic behaviour. In: Lawrence AB, Rushen J (eds): Stereotypic Animal Behaviour. Fundamentals and Applications to welfare. CAB International, Walingford, U.K. 1993, pp 97-118.

Liptrap RM, Cummings E: Steroid concentrations in follicular fluid of sows treated with dexamethasone. Anim. Reprod. Sci., 1991, 26, 303-310.

Liptrap RM: Effect of corticotrophin and corticosteroids on oestrus, ovulation and oestrogen excretion in the sow. J. Endocrinology, 1970, 47, 197205.

Merriam GR, Wachter K.: Algorithms for the study of episodic hormone secretion. Amer. J. Physiol., 1982, 243, E310-E318.

Moberg GP: How behavioral stress disrupts the endocrine control of reproduction in

domestic animals. J. Dairy Sci., 1991, 74, 304-311.

Munksgaard L: Metoder til vurdering af stress hos kvæg med fokus på adfærd, hypofysebinyrebarkaksen og væksthormonkoncentration (Methods for evaluation of stress in cattle with speciel references to behaviour, pituitary-adrenalcortical axis and growth hormone). Ph.D. afhandling. Den Kgl. Vet. og Landbohøjskole, Denmark, 1994, pp 128.

Paterson AM, Pearce GP: Boar-induced puberty in gilts handled pleasantly or unpleasantly during rearing. Appl. Anim. Beh. Sci., 1989, 22, 225233.

Pollard I, Cairncross KD: Ultrastructural changes in adenohypophysis adrenal gland activity and desynchronization of the oestrus cycle following unpredictable stress in rats. Aust. J. Biol. Sci., 1977, 30, 559-572.

Prunier A, Meunier-Salaün MC: The influence of boar stimulation on puberty attainment in tethered and group penned gilts. Theriogenology, 1989, 32, 949-959.

Przekop F, Wolinska-Witort E, Mateusiak K, Sadowski $B$, Domanski $E$ : The effect of prolonged stress on the oestrus cycles and prolactin secretion in sheep. Anim. Reprod. Sci., 1984, 7, 333-342.

Rampacek GB, Kraeling RR, Kiser TE: Delayed puberty in gilts in total confinement. Theriogenology, 1981, 15, 491-499.

Rivier $C$, Rivest $S$ : Review. Effect of stress on the activity of the hypothalamic-pituitarygonadal axis: Peripheral and central mechanisms. Biol. of Reprod., 1991, 45, 523-532.

Rivier C, Rivier J, Vale W: Stress-induced inhibition 
of reproductive functions: Role of endogenous corticotrophin-releasing factor. Science, 1986, 231, 607-609.

Siegel S, Castellan JR: Nonparametric statistics for the behavioral science. McGraw-Hill Inc., New York. 1988, pp 399.

SAS Institute Inc.: SAS user's guide. SAS Institute Inc., NC. 1986, pp 433-506.

Stupnicki R, Madej A: Radioimminoassay of LH in blood plasma of farm animals. Endokrinologie, 1976, 68, 6-13.

Weiner RI, Findell PR, Kordon C: Role of classic and peptide neuromediators in the neuroendocrine regulation of $\mathrm{LH}$ and prolactin. In: Knobil E, Neill J (Eds): The Physiology of Reproduction. Raven press, Ltd., New York. 1988, pp 12351281.

Xiao E, Luckhaus J, Niemann W, Ferin M: Acute inhibition of gonadotrophin secretion by corticotrophin-releasing hormone in the primate: Are the adrenal glands involved ?. Endocrinology, 1989, 124, 1632-1637.

\section{Sammendrag}

Sekretion af LH og østradiol under puberteten hos gylte udsat for gentagne electrochock.

Effekten af gentagne electrochock på LH og østradiol sekretionen og pubertetsalderen blev undersøgt hos 24 præpuberale sopolte. Tolv sopolte blev i alderen 115-168 dage udsat for uundvigelig electrochock 0-5 gange dagligt mellem kl. $8.00 \mathrm{og} 16.00$. Tolv andre sopolte indgik som kontroldyr. Da sopoltene var 168 \pm 0.7 dage gamle blev de flyttet, omgrupperet og udsat for $30 \mathrm{~min}$ ornekontakt. Herefter blev de observeret for brunst 2 gange dagligt. Dagen efter den første ornekontakt, blev der indlagt et permanent jugular kateter i 8 sopolte fra hver behandling. Herfra blev der udtaget blodprøver hvert 15 . min over 4 timer på dag 2 og 4 efter 1. ornekontakt med henblik på at bestemme LH profilen. På de resterende 4 sopolte fra hver behandling blev kateteret indlagt dagen før den 1. ornekontakt med henblik på tillige at bestemme LH profiler før ornestimulering. Der blev desuden udtaget blodprøver dagligt kl. 8.00, 12.00. og 16.00 de 3 første dage efter ornekontakten og herefter hver 4. time i døgnet indtil afslutningen på 1. brunst. Disse prøver blev analyseret for LH og østradiol for at bestemme størrelsen af den præovulatoriske LH- og østradioltop. Den basale plasma koncentration af cortisol blev bestemt, som gennemsnittet af prøver udtaget over de 5 første dage efter 1. ornekontakt. Electrochock behandlingen forlængede signifikant antallet af dage fra 1 . ornekontakt til 1 . brunst $(p=0.04)$ og tenderede til at sænke den basale plasma koncentration af $\mathrm{LH}(\mathrm{p}=0.08)$ samt at sænke den maksimale sekretion af LH under den præovulatoriske LH-top $(\mathrm{p}=0.07)$. Den tilsyneladende nedregulering af $\mathrm{LH}$ var ikke forårsaget af en forøget basal koncentration af cortisol i plasma, hvilket indikerer at andre fysiologiske mekanismer end øget aktivitet i HPA-aksen kan være involveret i stress-induceret inhibition af LH-sekretion.

(Received October, 1995; accepted February 12, 1996).

Reprints may be obtained from: L.J. Pedersen, The Royal Veterinary and Agricultural University. Department of Animal Science and Animal Health. Division of Ethology and Health, Bülowsvej 13, DK-1870 Frederiksberg C, Denmark. Phone +45 35283010, fax +45 35283022, E-mail: LJP@KVL.DK 
